\title{
Jekyll \& Hyde Online: A Critical Analysis on Consumption of the Self Through Advertisements Promoting Transhumanism
}

Sinem GÜDÜM, Marmara University, Advertising and Publicity. Assist. Prof. Dr. sinem.gudum@marmara.edu.tr, (D) 0000-0003-2488-3445

\begin{abstract}
R. Louis Stevenson's famous book called "Strange Case of Dr Jekyll and Mr Hyde" is an 1886 novel about a legal worker in London, who investigates the unprecedented events happening between his friend Dr Jekyll, and the evil counterpart Mr. Hyde. This story's impact has been such that the phrase "Jekyll and Hyde" still keeps coming up in conversations even today; referring to persons with an unpredictably dual nature. In order to understand the underlying reasons for the dualistic behavior amongst the humans, and their desperate search for perfection, 7 types of "Jakyll and Hyde" traits proposed by B.Engel will be discussed and analyzed through observing their appearances on advertisements, and how they lead to the consumption of the self in the era of transhumanism today. Qualitative methods, namely content analysis with semiotic undertones, will be applied on the chosen advertisement (Verizon, HTC Droid DNA) to make the necessary analysis on the topic together with a complimentary datamining sentiment analysis on 'Transhumanism' hashtag. To analyze the common public opinion on "transhumanism". Tweets under this hashtag between the 19th of January 2020 - 27th of January 2020 have been gathered by using 'Seobots' application, and then the collected data which held 108 tweets on the mentioned hashtag were analyzed by using the NVIVO program for sentiment analysis.
\end{abstract}

Keywords : : Transhumanism, Advertising, Human, Technology, Digital, Social Media

\section{Jekyll ve Hyde Çevrimiçi Olduğunda: Transhumanizmi Teşvik Eden Reklamlar Aracılığıyla Özün Tüketimi Üzerine Kritik Bir Analiz}

$\ddot{O Z Z}$

R. Louis Stevenson'un " Dr. Jekyll ile Bay Hyde" adlı ünlü kitabı, eski arkadaşı Dr Jekyll ile
kötü muadili bay Hyde arasında geçen benzeri görülmemiş olayları araştıran Londralı bir
hukukçunun hikayesini anlatır. Romanın etkisiyle "Jekyll ve Hyde" ifadesi deyimleşmiş ve
halk arasında, aşırı uçlarda seyreden ikili doğaya sahip kişilere atıfta bulunurken kullanılır
olmuştur. İnsandaki dualistik davranış biçimlerinin altında yatan nedenleri ve umutsuz
mükemmellik arayışlarının ardındaki kırılganlıkları irdelemek adına B.Engel tarafından
önerilen 7 tür "Jakyll E Hyde" özelliği, ve bunların reklamlarda transhumanizm
penceresinden bireyin tüketilmesi sonrası nasıl 'üst-insan' modelini inşa etmede kullanıldığı,
transhumanizmi konu alan bir reklama gelen sosyal medya twitleri irdelenerek analiz
edilmiştir. Konuyla ilgili gerekli analizlerin yapılabilmesi için seçilen reklama (Verizon, HTC
Droid DNA) kalitatif yöntemlerden içerik analizi, göstergebilimsel analiz eşliğinde
uygulanmış, aynı zamanda konuya ilişkin ek veri sağlayacak kullanıcı tepkisi ölçmek için de
19 Ocak 2021-27 Ocak 2021 arasında 'Transhumanizm' etiketi yapılmış olan tweetler
verimadenciliği ile seobots programı üzerinden toplanıp ayıklanarak 108 veri ile NVIVO
duygu analizi ile irdelenmiştir.

Anahtar : : Transhumanizm, Reklam, Insan, Teknoloji, Dijital, Sosyal Medya

Kelimeler 


\section{INTRODUCTION}

At the center of this study lies the dualistic unpredictability of the humans, caused by what Carl Jung named as their shadow side, which contains their animalistic desires, and potential destructive behaviors. It should be noted that the external influences like society, family, religion etc. reinforce certain attitudes, and thus urge a person to make unconcious and/or concious attempts to seperate the "shadow" from the self. This impossible attempt, makes the person condemn what is inseparable; the darker side... So, in this respect, can one really define who 'Mr. Hyde" is? Is he the 'real' person, the avatar, or both?

Acceptance of both 'personas', meaning the 'good' and 'the bad' may help to cherish and value one's humanity more in this relatively unknown era of transhumanism, where what is human is in danger of being replaced by the so called 'perfect', soulless machine.

As defining the 'persona' through consumption is coming to a dead-end after more then 100 years of magnificence, and as the need for the formation of its 'substitute' is emerging, one may say that the tele-reality of Baudrillard, is leaving its place to an 'opt-in reality' of the internet, where the people willingly participate in the formation of new 'cyber' realities that promise them some kind of 'perfection' that could not be reached in the real world. This may be one of the underlying resons behind the inevitable digitalization of the self today.

The person knows that he/she is not perfect in real life, but his/her cyber alter / avatar can be... So, the human is faced with some form of controlled demolition, where he/she starts destroying the real self by constantly feeding the avatar persona in the cyber realm, especially in social media. Is this human made 'simulacra' of the world that finds 'life' in avatars, making humans some pseudo- creators that face the irreversible danger of being trapped in their own deceit? Is the 'ego' of the modern man attempting to 'Play God' by deconstructing 'meaning' from all there is, and by manufacturing new definitions to find 'perfection' in a man-made world?

Since the beginning of time, one of mankind's biggest ambitions has been to create some artifacts that resemble their image. Today the evolution of humanoid robots can be considered as a simillar quest. 20th century brought along the explorations on connecting human intelligence with the machine; marking the beginning of an era of fertile research in the field of artificial intelligence (Siciliano \& Khatib, 2008, s.1-2).

As the academic writer Kim Toffoletti $(2007$, s.3) states, distinctions between what is real and what is virtual, where the body ends and technology begins, what is nature and what is machine, fracture and implode. Given this context, how can one understand what the self is, what a human is, what a man or a woman is?" 
Humans, as the unified embodiments of 'Jekyll and Hyde', tend to develop huge shadow sides that hold all their repressed emotions and desires locked up inside themselves. This dark side literally can take over an individual, causing him/her to create a seperate identity that is free to act out hidden desires (Engel, 2014, s.29). One may say that cyber (virtual) realities constitute a free-zone for such alter-lives. This may be the reason why people choose to have avatars on social media. One may even say that in some cases they love their avatars, and filtered faces more than their real appereances. And today, admiration for the avatar has come to shaping the real 'self' through transhumanism, and one may see how the public consent is carefully being manufactured by advertising today.

\subsection{ADVERTISING AND TRANSHUMANISM}

Audience engagement, and exposure through a variety of media have always been the main concern in advertising. But in todays high-tech world, the way marketing agencies use media are changing to get in line with the way the people collect information online. With the publicly announced projects of enhanced mental capacity and capability (Elon Musk's Neuralink Project is one example), and the chance of instant access to global networks by the so called 'augmented' human, will mass media and digital advertising continue in the same way as today? Will the ones who refuse to have the neural augmentation be able to coexist, let alone compete, with the ones who embrace it?

Consider making "phone calls" from one head to another without any apparent instrumentation which is planted inside the body. What kind of complications will this cause when some members of society have this capability while others do not? What about making difficult calculations in seconds, or retrieve information from the internet instantaneously? Neural augmentation will enable the human to do all that by compensating for individual cognitive deficits, but then again, will the end-result be a real 'human'? What happens to Dr. Jackyll when Mr. Hyde disappears?

Unfortunately, the more devout, respectable and altruistic a human seems to be in the eyes of the others, the more likely it is that he/she has a dark side waiting to get out. At this point it would be beneficial to point out the 7 types of 'Jakyll and Hyde's as follows (Engel, 2011, s.26-29):

Type 1: The abusive: When I become unhappy, it's your fault!

Type 2: The unpredictable: You never know when he/she will change.

Type 3: The classic: You only think you know me, but indeed you dont now me!

Type 4: The addict: Selfie craziness, second life formation, gameoholic youth etc...

Type 5: The imposter: If I do it, you do it!

Type 6: The 'All good' and 'all bad' person. 
Type 7: “I'm fine as long as you don't cross me!' person

When the individual rejects his/her dark side, and attempts to kill Mr. Hyde, with the evolving technology today, can the end result still be called a 'human'?

TV commercial by Verizon, HTC for its Droid DNA smartphone, can be regarded as one of the pioneers in transhumanist advertising, and this is the reason why it is chosen as an example for the purposes of this article. Please use your smartphone for QR code reading, or follow the link manually for the video:

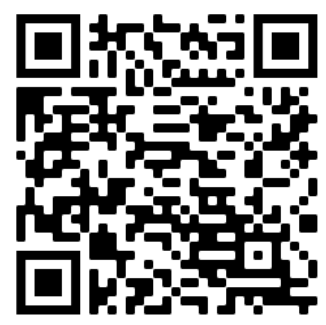

Advertisement. Psyop Inc. Directed by: Laurent Ledru, 2012. See: https://vimeopro.com/user18249711/commercials/video/79338042 (21.12.2020)

In this commercial, a man is prepared for a high-tech mechanical operation in a futuristic space. Seated in a chair and hooked on a device that covers his arm and thorax, a smartphone placed on his chest (gives the impression that it is his artificial 'heart'), activates the surgical apparatus. The outer voice says: "Droid DNA augmentation initiated" and the injection of nanobots that begin biologically hybridizing the subject's DNA. The procedure is also audibly told step by step: "Neural speed is increasing to 4G LTE;" " Brain upgrading to a quadcore processor," "Predictive intelligence with Google now complete" The augmentative sequence gets finalized, and the man (now a transhuman) lifts his gaze out onto a horizon of new, and limitless possibility. The narrator concludes: "lt is not an upgrade to your phone; it's an upgrade to yourself." (Wolyniak, 2015:35).

With the evolving technology, it is evident that more advertisements will be showing transhumanist scenes as such. However how much is this concept of transhumanism accepted by the society? Is it ethical to 'upgrade' a human just like a machine? Singh (2017), lists the technological developments which will be faced by humans in the near future as follows:

1. Body Augmentation: In his book titled "The Gutenberg Galaxy: The Making of Typographic Man", Marshall Mc Luhan (2002), predicted that technology will constitute the expansion of conciousness. Today, wearables can be considered as a form of body augmentation, but they will be surpassed by vision expanding contact lenses that can take pictures or video, earbuds that has hightened sound capabilities, 
bodysuits that increase physical strength etc... The use of implants ranging from RFID chips to mind-controlled 3D prosthesis and even Elon Musk's 'Neurolink' style memory storing... However, the most dehumanizing body augmentation is considered to be the biological augmentation and powerful CRISPR gene-editing technology which may result with the coming up of designer babies.

2. Faster and Transferable Thought Process: Humans may become a chain in the IOT (Internet of Things) system as the technology on Implantable brainmachine interfaces (BMIs) starts to be used. These Technologies are being tested by Elon Musk's Neuralink Project, DARPA projects, and social media (Facebook etc...). It is expected that such high technology devices inevitably will alter the ways humans communicate with each other, with the environment, and also with the machine (their digital devices and more...).

3. Increased Human Productivity: Gamification, behavioral science, and AI may lead to the enhancement of human potential. But the cost of addictive behavior may be high.

4. Increased emphaty through Virtual Reality: Schutte \& Stilinović (2017, s.1) stated that virtual reality experience results in greater engagement and a higher level of empathy for an individual. Virtual reality experience led to a higher level of two dimensions: 1. Empathic perspective taking 2. Empathic concern.

5. Extreme Personalization and customization: The smart home and smart life concepts can be regarded as pioneers of such developments.

6. Rise of AI and transformation of the workforce: Gerd Leonhard (2018) talks about the importance of 'automation' and says that as long as the humans give their moral responsibilities to the machines, then the cost of technological automation will be very high. The ethics become the focal point at this stage. Can Fauble's (2018, s.115-116) argument on handling the impacts of technology, and artificial intelligence, may be considered as a solution for this? Fauble says: "Men and women must no longer be valued by the wealth that they create for others, but the wealth they create for themselves through self-fulfillment." At this stage, it may be the time to decide what makes the human 'selffullfilled'; Will Dr. Jeykll survive without Mr. Hyde? And does he really want that?

\section{METHODS AND MATERIALS}

In this article, a conceptual framework on transhumanism in advertising is tried to be attained by conducting content analysis with semiotic undertones on the above mentioned advertisement (Verizon, HTC for its Droid DNA), together with a complimentary sentiment analysis on social media tweets for hashtag 'Transhumanism'. 
The analysis for the 'signifier' and the 'signified' in the above mentioned advertisement (Verizon, HTC for its Droid DNA) may give some clues over the way 'emotional appeals' are placed when using transhumanism in advertising. The signifier can be regarded as the tangible, material vehicle of meaning, and the signified shows the abstract dimension which actually is the real meaning. Some signifiers and signifieds on the Verizon advertisement may be shown as below:

The red button, located over the body part near the heart, can be given as a referent that stands for the 'humanization' of the 'machine'. Here actually there is a twist for the audience that needs to be noted; The subject is not a machine with a heart, it is a human in an operation room, about to get bionic parts. It may be said that the emphasis is put on the red button in the chest area, resembling the heart, to give some emotional appeal to the advertisement.

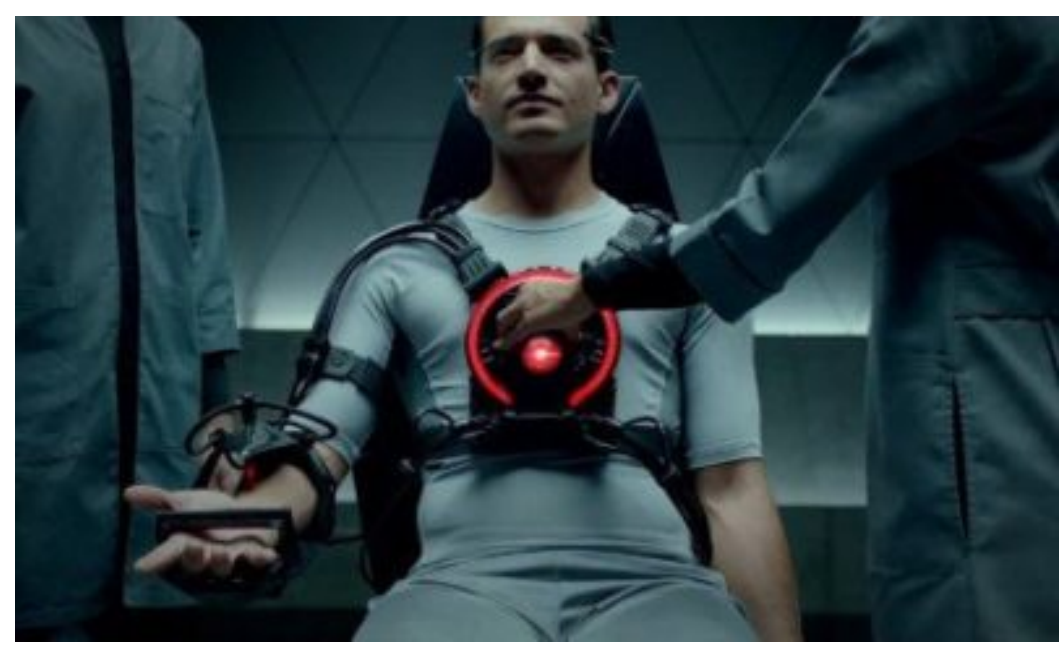

In the brand sensitive consumption society with the fear of missing out on the fast changing world of today, it is evident that the higher the technology, the better the mobile phone. However here with the slogan " It is not an upgrade to your phone; it's an upgrade to younself' a promise for 'more' is given... It promises a 'better you', while actually exchanging the subject with an object that can be modified and upgraded by the mankind himself.

When connected to the smart phone, the DNA of the human changes into a more mysterious looking, artificial string with electric circuts shown in red (which was associated with the heart before), still signifying that there is 'life' within the newly formed transhuman. 


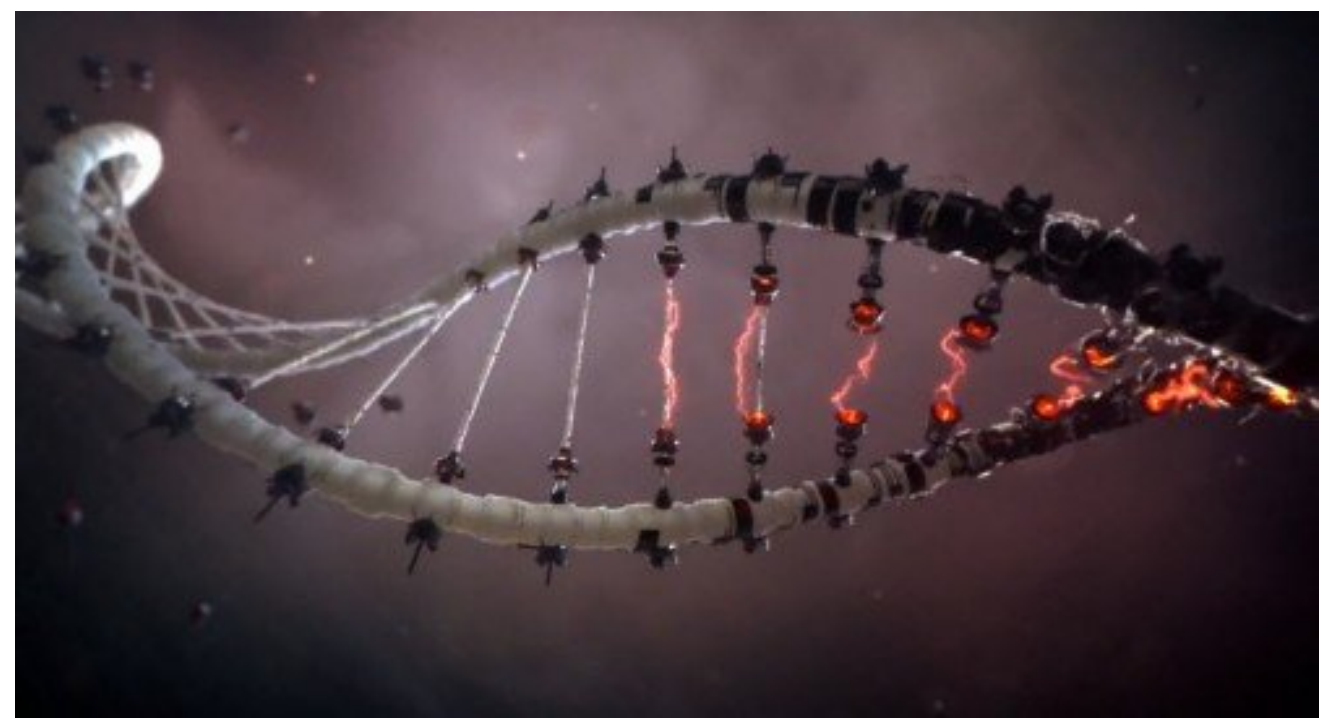

The overall connotative chain in the advertisement has dark and mysterious undertones which may resemble forbidden desires for reaching more power, and having control over both the body, and the universe.

In order to analyze the common public opinion on transhumanism, a search on \# (hashtag) transhumanism was made. Tweets which were posted on this specific hashtag between the 19th of January 2020 - 27th of January 2020 have been gathered by datamining through seobots application, and then the collected data which held 108 tweets on the hashtag was analyzed by using NVIVO sentiment analysis. The collected data can be seen in the excell tables below:

Table 1: Twitter Datamining Sample 1 (Hashtag Transhumanism / Comments 1-27)

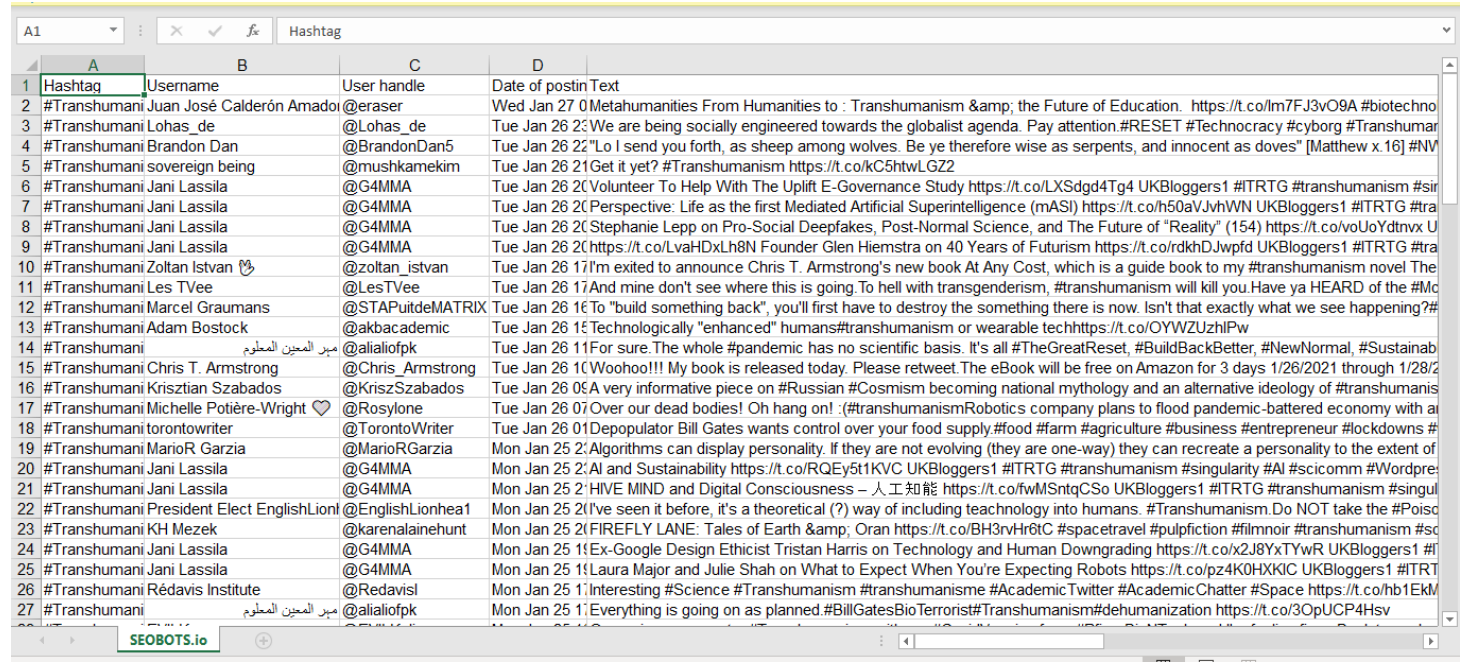


Table 2: Twitter Datamining Sample 2 (Hashtag Transhumanism/ Comments 28-51)

\begin{tabular}{|c|c|c|c|c|c|c|}
\hline \multirow[t]{2}{*}{ A1 } & r : & $\times \checkmark$ & Hashtag & & & \\
\hline & \multirow{2}{*}{$\frac{A}{H T r a n s h u m a n i}$} & & B & c & D & \\
\hline \multirow{2}{*}{\multicolumn{4}{|c|}{28 \#Transhumani EVILK }} & @EVILK_lives & Mon Jan 25 16:35:02+0000 2021 & On my journey now to \#Transhumanism with my \#CovidVaccine from \#Pfil \\
\hline & & & ater Satisfaction In Life & @Cagsil & Mon Jan 25 15:39:39+0000 2021 & \#NewWorldOrder / \#NWO is a $100+$ yr plan consisting of $100 \mathrm{~s}$ of $1000 \mathrm{~s} \mathrm{sm}$ \\
\hline 30 & \multicolumn{3}{|c|}{ \#Transhumani EATegrity } & @EATegrity_Sonia & Mon Jan $2512: 23: 42+00002021$ & 2017 - \#Transhumanism And The Future Of Humanity. 7 Ways The World \\
\hline 31 & \multicolumn{3}{|c|}{ \#Transhumani Steve Fuller } & @ProfSteveFuller & Mon Jan 25 11:59:37+0000 2021 & I'll be speaking (virtually) at the 'Being one and many: Faces of the human ir \\
\hline 32 & \multirow{2}{*}{\multicolumn{3}{|c|}{$\begin{array}{l}\text { \#Transhumani BioEdge } \\
\text { \#Transhumani Teslarati Verdad }\end{array}$}} & @bioedge & Mon Jan 25 08:22:39 +0000 2021 & "She argues that \#transhumanism will undercut liberal \#democracy, promol \\
\hline & & & & @TeslaratiVerdad & Mon Jan 25 05:21:57+0000 2021 & We all died before, perhaps even in prior lifetimes. We have been existing ir \\
\hline 34 & \multicolumn{3}{|c|}{ \#Transhumani Lou Haley } & @louhaley & Sun Jan $2421: 49: 23+00002021$ & \#transhumanism seems like a scary prospect where God needs to look the \\
\hline & \multicolumn{3}{|c|}{ \#Transhumani The Great Zambooni } & @TZambooni & Sun Jan 24 19:13:13+0000 2021 & Blood and Oil\#cyberpunk \#cyborg \#Transhumanism \#gore \#art \#pencil \#ch \\
\hline 36 & \multirow{2}{*}{\multicolumn{3}{|c|}{ \#Transhumani Zoltan Istvan $\mathbb{C}_{3}$}} & @zoltan_istvan & Sun Jan 24 19:03:07+0000 2021 & Some of my \#transhumanism work newly out at these links:https:/lt.co/6 $\mathrm{H} 4$ \\
\hline 37 & \multirow{2}{*}{\multicolumn{3}{|c|}{$\begin{array}{l}\text { \#Transhumani SatouHina } \\
\text { \#Transhumani SatouHina }\end{array}$}} & @SatouHina1 & Sun Jan 24 14:14:21 +0000 2021 & The Solution to all our Problems."Mhttps://t.co/TvLsJnzNXH\#Music \#Memes \\
\hline 38 & & & & @SatouHina1 & Sun Jan 24 13:49:03+0000 2021 & I think I know the Origin of the Greentext \&gt; Format. This is next Ivl genius; \\
\hline 39 & \multicolumn{3}{|c|}{ \#Transhumani SatouHina } & @SatouHina1 & Sun Jan 24 12:22:22 +0000 2 & Then He just sat there.I love talking with old \#Bill;YYou were the 2nd Host We \\
\hline 40 & \multicolumn{3}{|c|}{ \#Transhumani davs } & $@$ davs & Sun Jan $2408: 50: 00+00002021$ & More Concerns and Details about How the Internet of Bodies (loB) Will Liter \\
\hline 41 & \multicolumn{3}{|c|}{ \#Transhumani TrayDaCreator } & @traydacreator & Sun Jan 24 05:00:56+0000 2021 & \#transhumanism Bina 48 Meets Bina Rothblatt - Part One https:/lt.co/FplJ6 \\
\hline 42 & \multicolumn{3}{|c|}{ \#Transhumani \#Targetedlndividuals $\mathbf{0}$} & @CovertTorture & Sun Jan 24 01:04:24+0000 2021 & \#KlausSchwab \#GreatReset will lead to \#transhumanism \#wef https://t.co/ \\
\hline 43 & \multicolumn{3}{|c|}{ \#Transhumani Cheers for Tech } & @tech cheers & Sat Jan $2322: 58: 03+00002021$ & Join 13 people right now at "Technological stagnation: Why I came around" \\
\hline 44 & \multicolumn{3}{|c|}{ \#Transhumani Trapped in WorldAsylum :;) } & @claudia_kady & Sat Jan 23 21:13:07 +0000 2021 & A great interview with James Corbett and Catherine Austin on how the digite \\
\hline & \multicolumn{3}{|c|}{ \#Transhumani Filling Space } & @fillingspace_ & Sat Jan $2320: 03: 25+00002021$ & "To augment is neither to heal, nor to support, nor to accompany humankint \\
\hline 46 & \multicolumn{3}{|c|}{ \#Transhumani SpiritSamba } & $@$ MarkAnt72 & Sat Jan 23 18:30:08 +0000 2021 & The Internet of Bodies (loB) and Hacking Your DNAhttps://t.co/eZZsa7LF6E \\
\hline 47 & \multirow{2}{*}{\multicolumn{3}{|c|}{ \#Transhumani Citizens Attai }} & @Cagsil & Sat Jan 23 18:00:21 +0000 2021 & \#NewWorldOrder / \#NWO is a $100+y r$ plan consisting of $100 \mathrm{~s}$ of $1000 \mathrm{~s} \mathrm{sm}$ \\
\hline 48 & & & & $@$ Tr_INVISIBLE_Tr & Sat Jan $2317: 45: 06+00002021$ & Playing to lose: \#transhumanism, autonomy, and liberal democracy llong re \\
\hline 49 & \multicolumn{3}{|c|}{ \#Transhumani INV $V_{i} S_{i B L E}$} & @Atheism_is_Dead & Sat Jan 23 16:24:28 +0000 2021 & VIDEO: Ken Ammi, William Ramsey, Zak McGaha, et al, discuss gene editi \\
\hline 50 & \multicolumn{3}{|c|}{ \#Transhumani } & @alialiofpk & Sat Jan $2314: 40: 08+00002021$ & Its nothing more than prepping, priming of minds to swallow \#Transhumanis \\
\hline & \multicolumn{3}{|c|}{ \#Transhumani Jani Lassila } & QGAMMA & Sat Jan 23 07:07:19+0000 2021 & Chronos (Time as Geometrv) (1) httrs://tt. co/laiiHkrlld UKBlocaers1 \#ITRTG \\
\hline & & 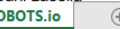 & & & & \\
\hline
\end{tabular}

Table 3: Twitter Datamining Sample 3 (Hashtag Transhumanism/ Comments 52-75)

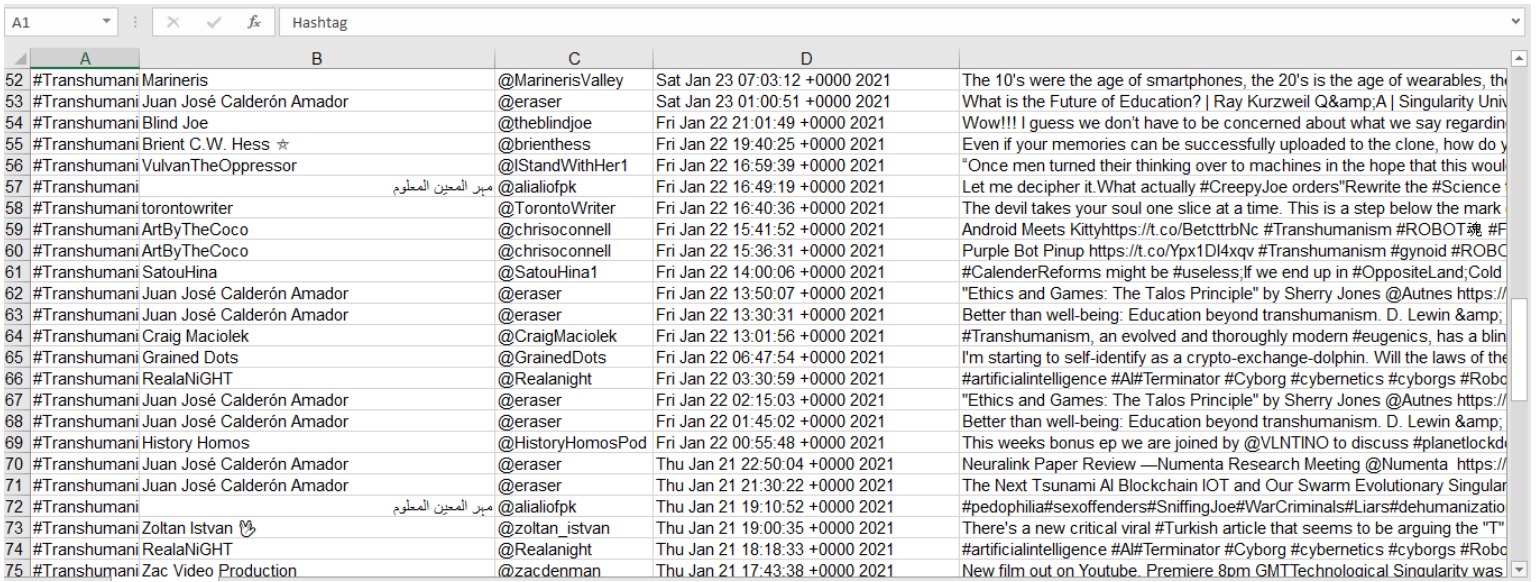

Table 4: Twitter Datamining Sample 4 (Hashtag Transhumanism / Comments 76-99)

A1
A1


Table 5: Twitter Datamining Sample 5 (Hashtag Transhumanism/ Comments 99-108)

\begin{tabular}{|c|c|c|c|c|c|c|}
\hline A1 & • & $\checkmark$ & \multicolumn{4}{|l|}{ Hashtag } \\
\hline & A & & B & C & D & \\
\hline \multicolumn{4}{|c|}{99 \#Transhumani Jamnoise72 } & @jamnoise72 & Tue Jan 19 23:40:47+0000 2021 & Marge Simpson's Talks About \#Geoengineering \&amp; \#Transhumanism F \\
\hline \multicolumn{4}{|c|}{100 \#Transhumani Juan José Calderón Amador } & @eraser & Tue Jan 19 22:10:04 +0000 2021 & Vulnerable Cyborgs: Learning to Live with our Dragons. Mark Coeckelbergr \\
\hline \multirow{2}{*}{\multicolumn{4}{|c|}{$\begin{array}{l}101 \text { \#Transhumani Jani Lassila } \\
102 \text { \#Transhumani Jani Lassila }\end{array}$}} & @G4MMA & Tue Jan 19 20:58:57 +0000 2021 & Immortalist Magazine No. 9 https://t.co/mNWYHpWplc UKBloggers1 \#TRT \\
\hline \multirow{2}{*}{\multicolumn{3}{|c|}{102 \#Transhumani Jani Lassila }} & & @G4MMA & Tue Jan 19 20:58:56 +0000 2021 & A Project Warp Speed for Our Minds https://t.co/sce0899mSB UKBloggers \\
\hline & & & & @Lauiec & Tue Jan 19 20:55:01 +0000 2021 & \#Transhumanism, that's where we're going to. \#StopTheGreatReset \\
\hline \multicolumn{4}{|c|}{104 \#Transhumani Edwardo } & @ERM_62 & Tue Jan 19 19:31:58+0000 2021 & Injectables appear more and more to not be as advertised, namely "vaccine \\
\hline \multicolumn{4}{|c|}{105 \#Transhumani POSTHÜMANIZM | TRANSHÜMANIZM } & @Posthumanizm & Tue Jan 19 19:02:21 +0000 2021 & \#TRANSHÜMANIZM NEDIR? |WHAT'S THE \#TRANSHUMANISM \\
\hline \multicolumn{4}{|c|}{106 \#Transhumani Jani Lassila } & @G4MMA & Tue Jan 19 18:09:59+0000 2021 & Artist Jon Marro on Living a Life of Creative Service (151) https://t.co/zMDkp \\
\hline \multirow{2}{*}{\multicolumn{4}{|c|}{107 \#Transhumani Zoltan Istvan $\mathbb{S}_{3}$}} & @zoltan_istvan & Tue Jan 19 17:54:12 +0000 2021 & I'm excited to share the feature documentary on my \#transhumanism and li \\
\hline \multirow{2}{*}{\multicolumn{4}{|c|}{$\begin{array}{l}108 \text { \#Transhumani Citizens Attain Greater Satisfaction In Life } \\
109 \text { \#Transhumani Morten Tolboll }\end{array}$}} & @Cagsiī & Tue Jan 19 17:09:46 +0000 2021 & \#NewWorldOrder / \#NWO is a $100+\mathrm{yr}$ plan consisting of $100 \mathrm{~s}$ of $1000 \mathrm{~s} \mathrm{sm}$ \\
\hline & & & & @LoaferTolboll & Tue Jan 19 16:57:02 +0000 2021 & Blog post: "The Return of The Sophists" (\#Facebook, \#PopularCulture, \#Ma \\
\hline \multicolumn{4}{|c|}{110} & & & \\
\hline
\end{tabular}

@SatouHina's tweet, which says "It's the solution to all problems" is accompanied by others that support transhumanism, and there are many others who have counter arguements like the tweet from @fillinspace_: "To augment is neither to heal, nor to support, nor to accompany humankind in its flourishing".

\section{RESULTS}

The semiotic analysis which was made for the "Verizon, HTC for its Droid DNA" advertisement, clearly showed some of the 'emotional appeals' that were used when using the transhumanist agenda in advertising. Afterwords, in order to calculate the sentiment beyond this transhumanist agenda, hashtag transhumanism was analyzed by datamining applications such as Seobots, and NVIVO.

In the sentiments analysis made on NVIVO with data collected by seobot's datamining applications, 108 tweets were analyzed. 77 tweets had the neutral message tone for the hashtag "Transhumanism", and this constitutes the majority of the tweets. This number is followed by 15 Positive, 10 negative and 6 mixed comments by sentiment analysis.

Table 6: NVIVO Sentiment Analysis Roundtable on \# Transhumanism

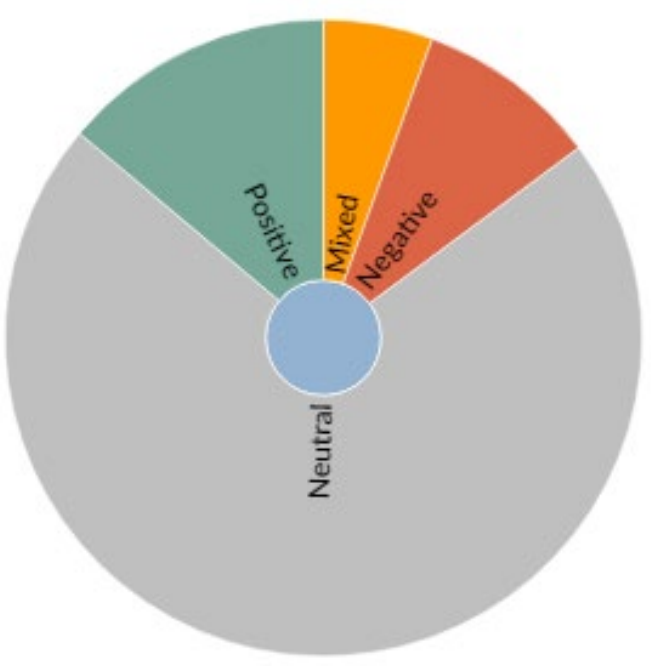


Table 7: NVIVO Sentiment Analysis Chart on \# Transhumanism

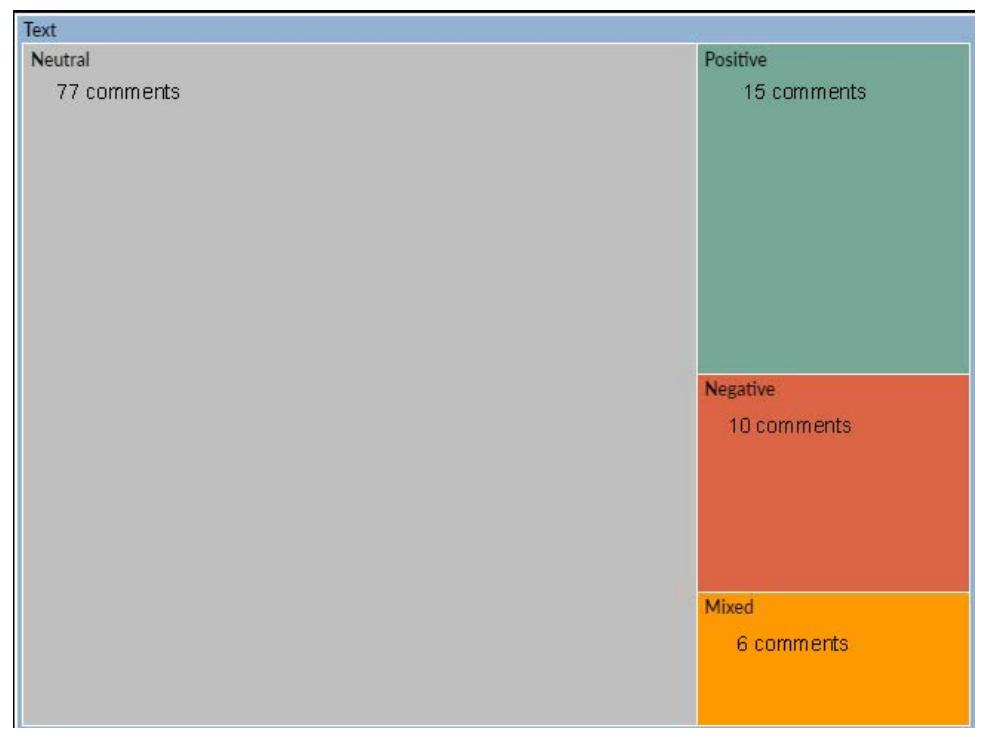

\section{CONCLUSION AND DISCUSSION}

The new-age notion of 'deconstructing the body' or 'cyborgification', together with transhumanism, can be seen in many movies, music clips, and advertisements today. From Shelley Jackson's “Patchwork Girl” to artist Henrik Olesen's “The body is a machine” exhibit, there are many examples of this transhumanist agenda.

At this point one may mention Scott Bukatman's (1993:315) definitions on the representation of the body in his book titled "Terminal Identity: The Virtual Subject in Postmodern Science Fiction" stating that the body is paradoxically extended by its own disappearance... Is it really an 'expention' that is reached with the avatarization of the self and the following transhumanization agenda? Or is it indeed the controlled 'destruction' of the self?

Braidotti (1994: 179) asks some questions which are important to consider in this respect: "What counts as human in this posthuman world? How do we rethink the unity of the human subject, without reference to humanistic beliefs, without dualistic oppositions, linking instead body and mind in a new flux of self? What is the view of the self that is operational in the World of the "informatics of domination?"

As proposed by Donna Haraway (1985:151), in her famous book "Simians, Cyborgs, and Women: The Reinvention of Nature", the concept of the cyborg is a rejection of rigid boundaries, notably those separating the "human" from animal and machine. She writes: "The cyborg does not dream of community on the model of the organic family; the cyborg would not recognize the Garden of Eden; it is not made of mud and cannot dream of returning to dust." At this point it would be appropriate to point out a dilemma which people may face in the digital world as technology advances: Staying in control of an immaculate pseudo-life that they 'created' on 
their somnambulist attempt to conquer life, and embrace it as their ultimate reality by rejecting life as it is today; or to have the courage to surrender their need of control the uncontrollable 'Hyde', and to embrace the power they find in the non-algorithmic 'imperfectibility' of the human.

\section{REFERENCES}

Braidotti, R. (994). Toward a New Nomadism: Feminist Deleuzian Tracks; or, Metaphysics and Metabolism. Gilles Deleuze and the Theater of PhiLosophy (eds: Boundas, C. and Olkowski, D.), 'New York: Routledge, 159-186

Bukatman, S. (1993). Terminal Identity: The Virtual Subject in Postmodern Science Fiction. UK: Duke University Press

Engel, B. (2011). The Jekyll and Hyde Syndrome: What to Do If Someone in Your Life Has a Dual Personalityor If You Do. USA: John Wiley \& Sons Publishing

Fauble, B. (2018). "The Rise of AI: Why the American Workforce Must Inevitably Change," Paideia: Vol. 5, Article 15, 98-116.

Haraway,D. (1985). Simians, Cyborgs, and Women: The Reinvention of Nature. USA: Routledge Publishing

Leonhard, G. (2018). Teknolojiye Karşı İnsanlık: Insan İle Makinenin Yaklaşan Çatışması. İstanbul: Siyah Kitap

Mc Luhan (2002), The Gutenberg Galaxy: The Making of Typographic Man. Canada: University of Toronto Press

Schutte, N. S., Stilinović, E. J. (2017). Facilitating Empathy Through Virtual Reality. Springer Onine: https://static1.squarespace.com/static/5d423a9a4416f400014a007a/t/5e214312a917cc6d1499b46a /1579238170754/Facilitating-Empathy-Through-VR.pdf (20.01.2020)

Singh, S. (2017). Transhumanism and the Future of Humanity: 7 Ways the World will Change by 2030. Forbes Magazine: www.forbes.com/sites/sarwantsingh/2017/11/20/transhumanism-and-thefuture-of-humanity-seven-ways-the-world-will-change-by-2030/?sh=7a6f58ef7d79 (20.12.2020)

Stevenson, R.L. (1886). Strange Case of Dr Jekyll and Mr Hyde. London: Longmans, Green and co.

Toffoletti, K. (2007). Cyborgs and Barbie Dolls: Feminism, Popular Culture, and The Posthuman Body. UK: I.B Tauris

Wolyniak, J. G. (2015). Progress and Progressio: Technology, Self-Betterment, and Integral Human Development. Journal of Moral Theology (ed. Caccamo, J.F. and McCarthy, D.M). Volume 4, Number 1: Technology Paperback. USA: Wipf \& Stock Publishing, 36-64 